\title{
Source apportionment vs. emission inventories of non-methane hydrocarbons (NMHC) in an urban area of the Middle East: local and global perspectives
}

\author{
Thérèse Salameh ${ }^{1,2,3, a}$, Stéphane Sauvage ${ }^{1,2}$, Charbel Afif ${ }^{3}$, Agnès Borbon ${ }^{4, b}$, and Nadine Locoge ${ }^{1,2}$ \\ ${ }^{1}$ Mines Douai, Sciences de l'Atmosphère et Génie de l'Environnement (SAGE), 59508 Douai CEDEX, France \\ ${ }^{2}$ Université de Lille, 59000 Lille, France \\ ${ }^{3}$ Emissions, Measurements, and Modeling of the Atmosphere (EMMA) Laboratory, Unité Environnement, \\ Génomique Fonctionnelle et Études Mathématiques, Centre d'Analyses et de Recherche, Faculty of Sciences, Saint Joseph \\ University, Beirut, Lebanon \\ ${ }^{4}$ Laboratoire Interuniversitaire des Systèmes Atmosphériques (LISA), IPSL, CNRS, UMR 7583, University of Paris Est \\ Créteil (UPEC) and Paris Diderot (UPD), Créteil, France \\ ${ }^{a}$ now at: Laboratoire Interuniversitaire des Systèmes Atmosphériques (LISA), IPSL, CNRS, UMR 7583, University of Paris \\ Est Créteil (UPEC) and Paris Diderot (UPD), Créteil, France \\ b now at: Laboratoire de Météorologie Physique (LaMP), CNRS - UMR 6016, University of Blaise Pascal, \\ Clermont-Ferrand, France
}

Correspondence to: Thérèse Salameh (therese.salameh@lisa.u-pec.fr)

Received: 7 August 2015 - Published in Atmos. Chem. Phys. Discuss.: 5 October 2015

Revised: 18 February 2016 - Accepted: 26 February 2016 - Published: 17 March 2016

\begin{abstract}
We applied the positive matrix factorization model to two large data sets collected during two intensive measurement campaigns (summer 2011 and winter 2012) at a suburban site in Beirut, Lebanon, in order to identify NMHC (non-methane hydrocarbons) sources and quantify their contribution to ambient levels. Six factors were identified in winter and five factors in summer. PMF-resolved source profiles were consistent with source profiles established by near-field measurements. The major sources were traffic-related emissions (combustion and gasoline evaporation) in winter and in summer accounting for 51 and $74 \mathrm{wt} \%$, respectively, in agreement with the national emission inventory. The gasoline evaporation related to traffic source had a significant contribution regardless of the season $(22 \mathrm{wt} \%$ in winter and $30 \mathrm{wt} \%$ in summer). The NMHC emissions from road transport are estimated from observations and PMF results, and compared to local and global emission inventories. The PMF analysis finds reasonable differences on emission rates, of 20-39\% higher than the national road transport inventory. However, global inventories (ACCMIP, EDGAR, MACCity) underestimate the emissions up to a factor of 10 for the
\end{abstract}

transportation sector. When combining emission inventory to our results, there is strong evidence that control measures in Lebanon should be targeted on mitigating the NMHC emissions from the traffic-related sources. From a global perspective, an assessment of VOC (volatile organic compounds) anthropogenic emission inventories for the Middle East region as a whole seems necessary as these emissions could be much higher than expected at least from the road transport sector.

\section{Introduction}

Fast urbanization expansion, high population density, industrialization, intensive transport networks, and negligent pollution control have led to a substantial degradation of air quality in the Middle East (MEA) region (UNEP, 2006). Nowadays, air quality is taken as a major aspect of the quality of life leading to sustainable development in many areas of the world.

In Lebanon, a developing country in the MEA, which is located in Western Asia on the eastern shore of the Mediter- 
ranean Sea, air quality has continuously deteriorated leading to high pollutant levels exceeding the World Health Organization (WHO) recommended values (WHO, 2005); for instance, Afif et al. (2009) reported an annual average concentration of nitrogen dioxide $\left(\mathrm{NO}_{2}\right)$ in Beirut from December 2004 to June 2006, of $67 \mu \mathrm{g} \mathrm{m}^{-3}$ which is higher than the WHO annual recommended value of $40 \mu \mathrm{g} \mathrm{m}^{-3}$ (WHO, 2005). In addition, high levels of particulate matter, $\mathrm{PM}_{10}$ and $\mathrm{PM}_{2.5}$, were obtained with annual concentrations of 64 and $20 \mu \mathrm{g} \mathrm{m}^{-3}$ respectively (Massoud et al., 2011), exceeding WHO guideline values of 20 and $10 \mu \mathrm{g} \mathrm{m}^{-3}$. Although these measurements provide valuable information on air pollution, they are scarce and limited to a few pollutants. In the absence of adequate environmental policy and action, Lebanon is facing today significant urban air pollution problems; the cost of degradation of air quality was last estimated in 2001 at $1.02 \%$ of the annual gross domestic product (GDP) (Sarraf et al., 2004).

Among air pollutants, non-methane hydrocarbons (NMHCs) play an important role in urban areas since they contribute to the formation of photochemical oxidants such as ozone and peroxyacetylnitrate (PAN) and they are also involved in the formation of secondary organic aerosols (SOA) (Seinfeld and Pandis, 2006). Moreover, some species are associated with adverse health effects or are even carcinogenic (e.g., benzene, 1,3-butadiene, etc.) (WHO, 2000).

NMHCs are emitted mainly from anthropogenic sources in urban areas. Major anthropogenic sources include vehicle exhaust, fuel evaporation, solvent use, emissions of natural gas and industrial processes (Friedrich and Obermeier, 1999; Sauvage et al., 2009). While urban emission sources of NMHC are usually well identified, their relative importance is still under debate and can be region-dependent (Yuan et al., 2013).

Considering the diversity in chemical reactivity among NMHCs, their different ozone and SOA formation potentials (Carter, 1994; Derwent et al., 2010) and the speciation profiles of the various emission sources, there is a clear need to identify and quantify NMHC emission sources, and their associated speciation by the development of regional emission inventories in order to apply efficient control strategies and air pollution management.

Moreover, emission inventories are used as input data for air quality models; therefore, their accuracy is also important for air quality impact assessment. However, recent in situ observations have revealed persistent and high uncertainties in emission inventories in urban areas of post-industrialized countries. Borbon et al. (2013) found large discrepancies between observed emissions ratios and those calculated from the inventories in Los Angeles and Paris. Moreover, Gaimoz et al. (2011) showed that the current emission inventory for Paris strongly overestimates the volatile organic compounds (VOCs) emitted from solvent use and needs to be corrected. Niedojadlo et al. (2007) also revealed some inconsistency be- tween emission inventory in Germany and source apportionment results, especially regarding emissions related to solvent use. Those studies have revealed that source-receptor approaches could be a relevant alternative to emission inventories where provided observations are available.

For the MEA region, emissions uncertainties could be even higher. At present, local inventory, emission data and observations for their evaluation are sparse and not speciated, potentially resulting in higher uncertainty in modeling approaches (Waked and Afif, 2012; Waked et al., 2013). In particular, there is a paucity of data on NMHC levels and their emission sources in the Middle East region. At the global scale, several emission inventories exist but very few of them are speciated or exhibit fine temporal resolution (ECCAD database, 2015, http://eccad.sedoo.fr). For Lebanon, a recent work has led to the development of an atmospheric emission inventory of anthropogenic and biogenic sources considering $\mathrm{CO}, \mathrm{NO}_{x}, \mathrm{SO}_{2}, \mathrm{NMVOC}, \mathrm{NH}_{3}, \mathrm{PM}_{10}$, and $\mathrm{PM}_{2.5}$, for a base year of 2010 according to the 2009 EMEP/EEA guidelines (EMEP/EEA 2009; Waked et al., 2012).

The aim of this work is to identify major NMHC sources and quantify their contribution to NMHC concentrations on a seasonal basis by applying the source-receptor positive matrix factorization model (PMF) to the observations collected at a suburban site in the urban area of Beirut, Lebanon, and evaluate its consistency with existing emission inventories. The receptor modeling techniques are numerous; many of them have been previously used in NMHC source apportionment worldwide including principal component analysis (PCA), positive matrix factorization (PMF), chemical mass balance (CMB) and UNMIX like in Europe (Badol et al., 2008; Sauvage et al., 2009), the USA (Leuchner and Rappenglück, 2010), and in China (Guo et al., 2007; Yuan et al., 2013). The performance of four receptor models (PCA, PMF, CMB and UNMIX) was evaluated by Miller et al. (2002) by applying them to the same artificial data set of VOCs. They found that PMF extracted factor profiles that most closely represented the major sources used to generate the simulated data, and concluded that PMF is the most appropriate model to explain the results (Miller et al., 2002).

A large set of speciated NMHC have been continuously measured during 2-week periods in summer 2011 and winter 2012 in the frame of the Emission and Chemistry of Organic Carbon in the Eastern Mediterranean (ECOCEM) experiment. The consistency of the source composition obtained by the PMF on a seasonal basis is evaluated with regards to NMHC source profiles established by canister sampling in the vicinity of emission sources (Salameh et al., 2014). Finally, PMF results are used to evaluate local and global emission inventories. 


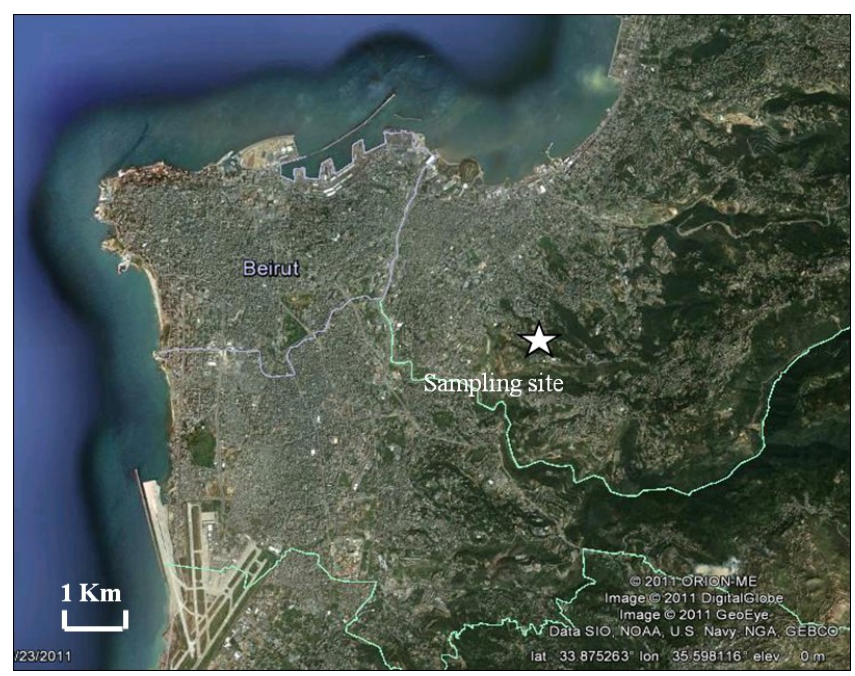

Figure 1. Sampling site in the eastern suburb of the city of Beirut.

\section{Experimental procedures}

\subsection{Sampling site: location and surroundings}

The site was chosen in a way to be far enough from strong direct emissions (industrial, road transport) since they can hide the emissions from distant sources. At the same time, the site is appropriately located in order to receive the air masses coming from the Greater Beirut Area (Fig. 1). The measurements were conducted on the roof of the Faculty of Sciences building of Saint Joseph University $\left(33^{\circ} 87^{\prime} \mathrm{N}\right.$, $\left.35^{\circ} 56^{\prime} \mathrm{E}\right)$ from 2 to 18 July 2011 in summer and again from 28 January to 12 February 2012 in winter. The site is located in the eastern suburb of the city of Beirut $(6 \mathrm{~km}$ southeast of Beirut downtown) at an altitude of $230 \mathrm{~m}$ a.s.l. (above sea level). The site is surrounded by a forested pine area and a high density of residential premises. Beirut International Airport is located $8 \mathrm{~km}$ southwest of the site and one fuel storage facility is located at $3.6 \mathrm{~km}$ north (Salameh et al., 2014).

\subsection{Material and methods}

NMHCs were continuously analyzed by on-line Thermal Desorption Gas Chromatography with a Flame Ionization Detector (TD-GC-FID) provided by Perkin Elmer described elsewhere (Salameh et al., 2014). The on-line measurement was performed hourly, covering $30 \mathrm{~min}$ of ambient air sampling. Sixty seven NMHCs from C2 to C9 belonging to alkanes (29), alkenes (19), alkynes (2) and aromatics (17) were identified and quantified. The detection limits were around 40 pptv for the targeted compounds except for ethane and ethylene (90 pptv). A certified NPL (National Physical Laboratory) standard of NMHC mixture ( $\sim 4 \mathrm{ppbv})$ was used to determine and check the stability of the GC carbon response during both measurement periods. The data have been published in Salameh et al. (2015).
Additional trace gases including carbon monoxide (CO), $\mathrm{NO}_{x}$ and $\mathrm{O}_{3}$ were measured on-line on a $1 \mathrm{~min}$ basis using trace gas analyzers. Basic meteorological parameters (wind speed and direction, temperature, relative humidity and atmospheric pressure) were measured on a $1 \mathrm{~min}$ basis during both campaigns.

\section{Source apportionment by positive matrix factorization (PMF)}

\subsection{PMF model description}

The USEPA PMF v3.0 was applied for NMHC source apportionment analysis. This method is described in details elsewhere (Paatero and Tapper, 1994; Paatero, 1997). NMHCs which are not identified during both seasons (like tetrachloroethylene) or their concentrations were frequently below the detection limits were not considered in the PMF analysis.

According to the PMF, an observed concentration at a receptor site can be viewed as a data matrix $\mathbf{X}$ of $i$ by $j$ dimensions in which $i$ number of samples and $j$ chemical species were measured.

$x_{i j}=\sum_{k=1}^{p} g_{i k} f_{k j}+e_{i j}$,

where $g_{i k}$ is the mass contribution of the $k$ th source to the $i$ th sample, $f_{k j}$ is the $j$ th species mass fraction from the $k$ th source, $p$ is the number of independent sources, and $e_{i j}$ is the residual associated with the concentration of the $j$ th species in the $i$ th sample. The solution of the equation is obtained by minimizing the residual sum of squares $Q$ given by

$Q=\sum_{i=1}^{n} \sum_{j=1}^{m} \frac{e_{i j}^{2}}{s_{i j}^{2}}=\sum_{i=1}^{n} \sum_{j=1}^{m}\left(\frac{x_{i j}-\sum_{k=1}^{p} g_{i k} f_{k j}}{s_{i j}}\right)^{2}$,

where $f_{k j} \geq 0$ and $g_{i k} \geq 0$ and where $n$ is the number of samples, $m$ the number of considered species, and $s_{i j}$ an uncertainty estimate for the $j$ th species measured in the $i$ th sample.

The results are constrained so that no sample can have significantly negative source contributions. The goal is to identify the number of factors $p$, the species profile $f$ of each source, and the amount of mass $g$ contributed by each factor to each individual sample by using measured source profile information, meteorological parameters analysis, and additional species.

\subsection{PMF model implementation}

One of the advantages of the PMF is to consider the uncertainty of each individual concentration. Special attention was paid to the estimation of the uncertainty. For each measured concentration, an uncertainty was calculated following 
the method developed within the ACTRIS (Aerosols, Clouds, and Trace gases Research InfraStructure) network (Hoerger et al., 2015, see their Supplement). It includes the systematic errors in the measurement and the precision which reflects the random errors. Thus, the total uncertainty of a measurement is obtained with Eq. (3):

$\Delta x^{2}$ unc $=\Delta x^{2}$ precision $+\Delta x^{2}$ systematic.

The precision is derived from a series of measurements of the NPL standard gas. It covers the random errors of the sampling and analytical system.

Possible systematic errors include the calibration gas uncertainty, systematic peak integration errors, sample volume determination, and potential blank value (Hoerger et al., 2015, see their Supplement). Therefore, the overall systematic error is described as follows:

$$
\begin{aligned}
\Delta x^{2} \text { systematic }= & \Delta x^{2} \text { calibration }+\Delta x^{2} \text { integration } \\
& +\Delta x^{2} \text { volume }+\Delta x^{2} \text { blank }
\end{aligned}
$$

The systematic integration error can be neglected because the chromatograms (peak shapes of the considered species and the form of the baseline) were quite similar for air samples and for the calibration gas.

The systematic volume error is neglected since $\delta V_{\text {sample }}=\delta V_{\text {calibration }}$.

For the expanded uncertainty, the total uncertainty calculated is multiplied by the coverage factor $k=2$.

The relative expanded uncertainty ranged between 4 and $27 \%$ in summer for all the compounds except for octane which was $38 \%$. In winter, the relative expanded uncertainty was between 5 and $35 \%$ for most of the compounds except for trimethylbenzenes, isoprene, octane and heptane which had an uncertainty between 40 and $60 \%$.

The missing data were replaced by the median of the concentrations measured the other days at the same hour; and in these cases, the uncertainty was set as four times the concentration. Values reported as below DL were replaced by half of the DL and the corresponding uncertainty was set as $5 / 6$ of the DL value.

Paatero and Hopke (2003) have introduced the signal-tonoise ratio $(S / N)$ which takes into consideration the concentration $(x)$ and the uncertainty $(s)$ of the species $(j)$ (Eq. 5). This ratio indicates whether the variability in the measurements is real or within the noise of the data. A compound characterized by low concentrations or by a large number of observations (i) associated with relatively high uncertainties will have a low $S / N$ ratio. If the $S / N$ ratio is less than 0.2 , the species is excluded and if the ratio is greater than 0.2 but less than 2 , the uncertainty is multiplied by four.

$$
\left(\frac{S}{N}\right)_{i}=\sqrt{\sum_{j=1}^{n}\left(x_{i j}-s_{i j}\right)^{2} / \sum_{j=1}^{n} s_{i j}^{2}}
$$

For a reliable identification of the sources, the PMF requires a large number of samples. The large data sets collected during the two campaigns, 298 samples in summer and 179 samples in winter, were lumped separately for PMF source apportionment seasonal analysis. By taking into consideration the different existing reactivities, mainly with $\mathrm{OH}$ radical within the NMHC species, the profile of each source may change temporally during transport of emission plumes. Nevertheless, we have examined the factors influencing the distribution of NMHCs (Salameh et al., 2015) and we concluded that NMHCs were freshly emitted from local sources in winter but also in summer, and the chemical losses of NMHC species, even for the most reactive species, were likely not significant.

\subsection{Determination of the optimal solution}

Several base runs were performed with a different number of factors from 3 to 12 . The diagnostic parameters include the value of $Q$, IM which is the maximum individual column mean and IS which is the maximum individual column standard deviation defined by Lee et al. (1999). $Q$, IM, and IS are then plotted against the number of factors (from 3 to 12). The number of factors chosen corresponds to a significant decrease of $Q$, IM, and IS. In order to control the rotation and to optimize the selected solution, the $F_{\text {peak }}$ parameter was used. Six factors were extracted from winter data set and five from summer data set. Quality indicators from the PMF application are summarized in Table 1.

\section{Results and discussion}

\subsection{Meteorological conditions}

Lebanon is characterized by a narrow coastal strip located on its western part and by the Bekaa valley located between the western and eastern Lebanese mountain chains. The coastal region has a Mediterranean climate with land-sea breeze circulation. During the summer measurement campaign, the temperature at the Saint Joseph University site ranged from 20 to $29^{\circ} \mathrm{C}$ with an average of $25^{\circ} \mathrm{C}$. The average wind speed was $2 \mathrm{~m} \mathrm{~s}^{-1}$ with a maximum wind speed of $10 \mathrm{~m} \mathrm{~s}^{-1}$ during the day coming mostly from the southwest and from the north on 7, 8 and 9 July. The wind direction was mostly from the northeast and slightly from south, southwest at night. During the winter measurement campaign, the temperature ranged from 7 to $22^{\circ} \mathrm{C}$ with an average of $13^{\circ} \mathrm{C}$. The average wind speed was $2 \mathrm{~m} \mathrm{~s}^{-1}$ and the wind direction was mostly coming southeasterly and easterly (Salameh et al., 2015).

\subsection{Identification of PMF profiles}

In order to attribute PMF factors to emission sources, a comparison between extracted PMF profiles and speciated profiles established in the vicinity of emission sources by 
Table 1. Mathematical diagnostic for the PMF results.

\begin{tabular}{lrr}
\hline & Summer & Winter \\
\hline$n$ (samples) & 298 & 179 \\
$m$ (species) & 59 & 59 \\
$k$ (factors) & 5 & 6 \\
$Q$ (model) & 5670 & 1728 \\
NMHC $_{\text {modelled vs. NMHC }}$ measured $(R)$ & 0.97 & 0.99 \\
$F_{\text {peak }}$ & -0.5 & 0 \\
Mean ratio (modeled vs. measured) & 1.05 & 0.99 \\
Number of species with $R^{2}>0.75$ for modeled vs. measured & 39 & 29 \\
\hline
\end{tabular}

Salameh et al. (2014) was carried out, when possible. In addition, the diurnal cycle and time series of the contributions of modeled sources were analyzed with independent parameters like meteorological data and specific tracers like $\mathrm{CO}$ and $\mathrm{NO}_{x}$.

\subsubsection{Winter PMF factor identification and contribution}

In winter, six sources were identified corresponding to combustion mainly related to regional traffic, combustion related to local traffic, gas leakage, gasoline evaporation related to traffic, gasoline evaporation as an episodic point source and a source characterizing the urban background. The composition of the source profiles and the diurnal variations of the source contribution are reported in Figs. 2 and 3, respectively.

\section{Background}

Long-lived species are dominant in factor 1 . The ethane and propane variability explained by this factor is 76 and $42 \%$ respectively, even though, toluene, butane and acetylene are also present in this profile. This factor is, therefore, categorized as urban background (Lanz et al., 2008; Sauvage et al., 2009). The diurnal profile of this factor does not show any significant peak and instead maintains the same contribution independently of the hour of the day (Fig. 3). The average relative contribution of this factor is $18 \%$ in winter.

\section{Combustion mainly related to regional traffic}

Factor 2 has significant amounts of toluene, m,p-xylenes, ethylbenzene, ethylene, acetylene, 1,2,4-trimethylbenzene and decane (co-eluted), and benzene which are typical combustion products. Almost $30 \%$ of the variances of ethylene, propene, acetylene and benzene are explained by this factor. This profile is very similar to the profile determined in the vicinity of the emission sources in Beirut which consists of exhaust and evaporative running losses from vehicles (Salameh et al., 2014). The factor contribution is well correlated with the concentrations of $\mathrm{CO}$ and $\mathrm{NO}_{x}$ which are combustion tracers ( $R=0.8$ and 0.7 , respectively). The daily time series of the contribution of this source are character-
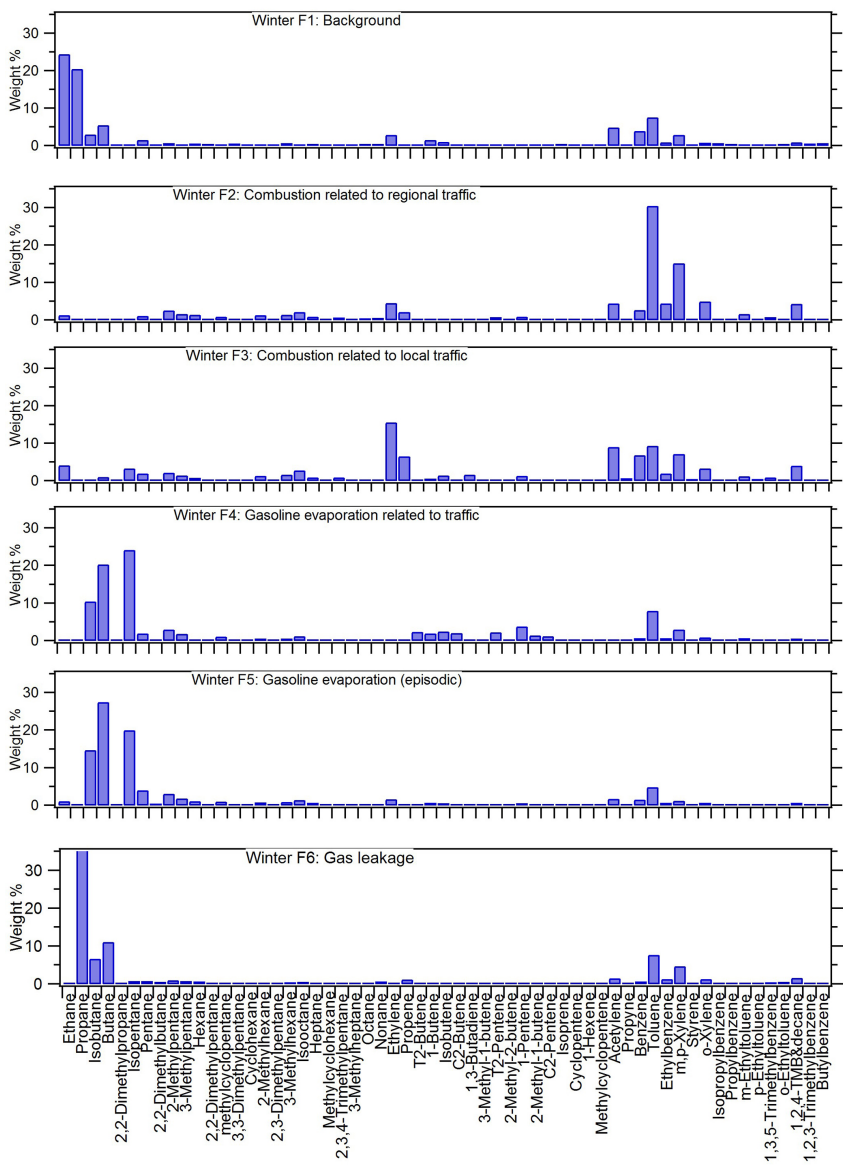

Figure 2. Source composition profiles (relative abundance of specific compounds within each factor in wt \%) in winter 2012.

ized by a first significant increase of concentrations at around 07:00-08:00 LT (UTC/GMT+2 h), the second one at 14:00 15:00 LT, another increase at 17:00-18:00 LT and a small peak is observed at 20:00-21:00 LT in the evening. According to Waked et al. (2012), the diurnal variation profile for on-road mobile source in urban areas in Lebanon shows two significant increases in weekdays, a morning peak at around 07:00-10:00 LT and an evening peak from 16:00 to 18:00 LT consistent with the important peaks observed for factor 2 . 


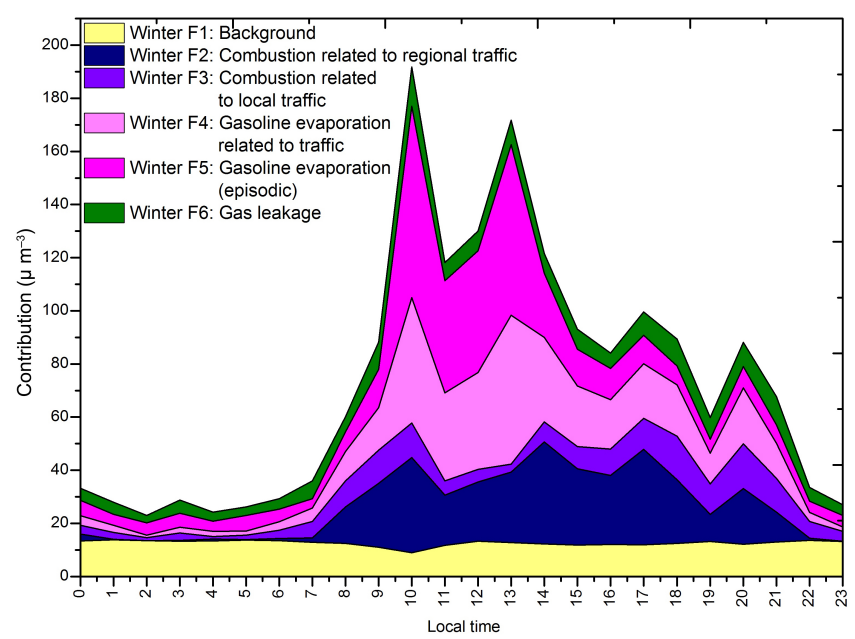

Figure 3. Diurnal variation of source contribution $\left(\mu \mathrm{g} \mathrm{m}^{-3}\right)$ to NMHC concentrations in winter 2012.

In addition, in winter, additional sources related to domestic heating should be considered since the measurement site is surrounded by residential area. The average relative contribution of this factor is $19 \%$ in winter.

Factor 3 is also characterized by some combustion tracers (ethylene, acetylene, toluene, benzene, propene, and $\mathrm{m}, \mathrm{p}$ xylenes). Nearly $50 \%$ of the variances of ethylene as well as propene are explained by this factor. The factor contribution strongly correlates with $\mathrm{CO}$ and $\mathrm{NO}_{x}(R=0.8$ and 0.7 respectively). This factor is associated to "combustion related to local traffic" since it does not show a significant contribution during the weekend which is due to the limited local activity nearby the measurement site (schools, universities, residential area). The daily variation of this factor is characterized by an initial increase at 07:00-08:00 LT, a peak at 18:00-19:00 LT and the last peak in the evening at 20:0021:00 LT. These enhancements are far less than those of factor 2 . The average relative contribution of this factor is $10 \%$ in winter.

\section{Gasoline evaporation related to traffic}

Isopentane, butane, isobutane, toluene and 2-methylpentane are the main compounds of factor 4 . Most of isopentane $(53 \%)$ and around $36 \%$ of butane and isobutane are explained by this factor. This strongly suggests that this profile is related to fuel evaporation. Additionally, the profile of this factor, taking into account the larger NMHC contributors, is compared to three gasoline evaporation profiles established by near-field measurements including the fuel storage facilities, hot soak (a type of evaporative emissions which occurs when a warmed-up vehicle is stationary and the engine is stopped) and refueling cars (Salameh et al., 2014) in Fig. 4. The fingerprint is consistent within all the gasoline evaporation source profiles confirming the nature of this source. In

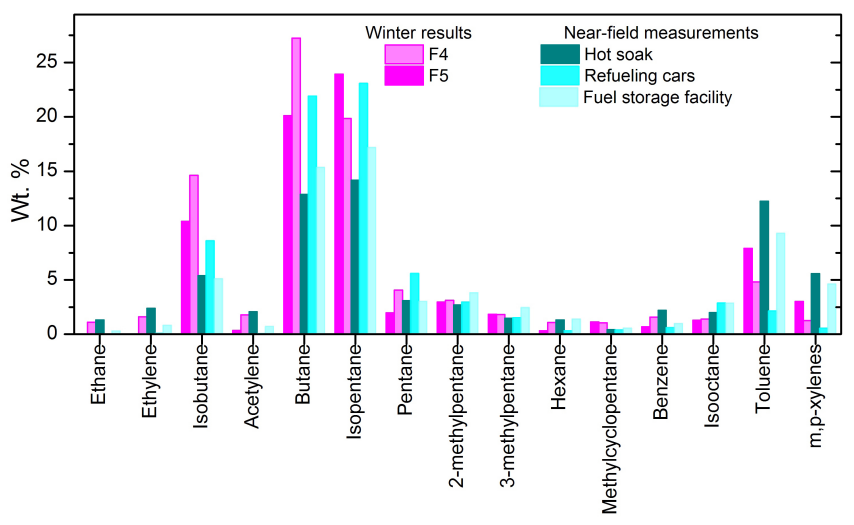

Figure 4. Composition profiles (wt \%) of two gasoline evaporation factors (F4 and F5) in winter compared to typical gasoline evaporation profiles established by near-field measurements (Salameh et al., 2014).

Lebanon, light-duty vehicles operate on gasoline while only heavy-duty vehicles are allowed to run on diesel (4\% of fleet in Beirut) (Waked and Afif, 2012). The diurnal profile as well as the time series in Fig. 5 display the same aforementioned peaks in factors 2 and 3 especially in the morning and in the evening assuming that the gasoline evaporation is linked to traffic. The average relative contribution of this factor is $22 \%$ in winter.

\section{Gasoline evaporation}

Factor 5 is also characterized by the $\mathrm{C} 4-\mathrm{C} 5$ alkanes, toluene and 2-methylpentane. Nearly $42 \%$ of the isopentane and pentane variability and $48 \%$ of the isobutane and butane variability are explained by this factor. The fingerprint of the chemical composition is consistent with the ones of typical gasoline evaporation profiles established by near-field measurements (Fig. 4). The diurnal profile of this source contribution is marked by a night minimum and an increase in the midday. The time series presented in Fig. 5 shows that this factor (F5) is primarily episodic with high contribution originating from the north wind sector as demonstrated in the pollution rose in Fig. 6. The extremely high levels of the source contribution come from the north sector where the fuel storage facilities are located (Fig. 6). A collinearity between both gasoline evaporation factors (F4 and F5) is observed around noon when the wind blows from the north sector since the highest contributions are detected in this sector making the apportionment difficult. The average relative contribution of this factor is $21 \%$ in winter.

\section{Gas leakage}

$58 \%$ of propane variability is explained by factor 6 . The composition of this source is mainly impacted by high loadings of propane, butane and isobutane which are the signatures of LPG (liquified petroleum gas) (Blake and Rowland, 


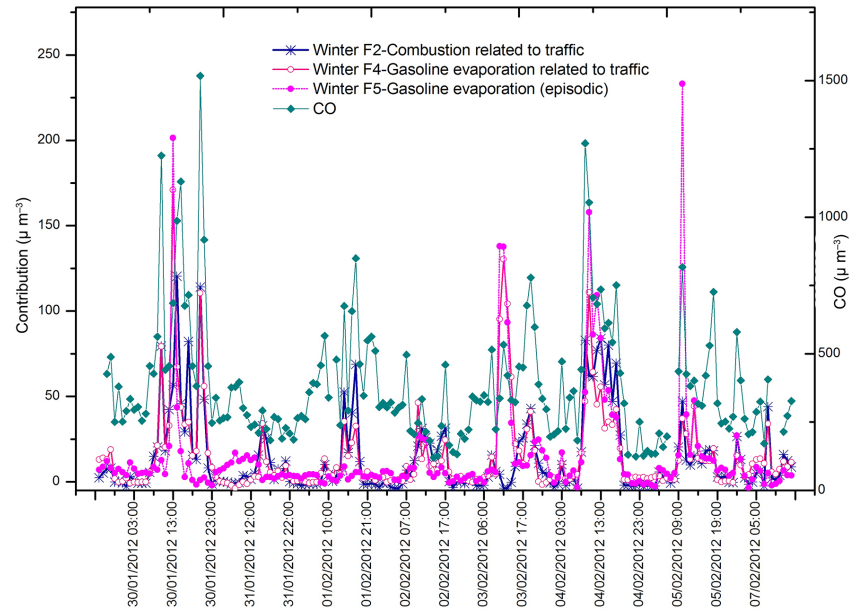

Figure 5. Time series of winter combustion related to traffic (F2), gasoline evaporation (F4 and F5), factors contribution, and $\mathrm{CO}$ in $\mu \mathrm{g} \mathrm{m}^{-3}$.

1995). Hence, this source is attributed to gas leakage, mainly LPG, from residential use. LPG is the main fuel for cooking in households in Lebanon and it is used, among others, for domestic heating. The diurnal profile of this factor does not show significant peaks, only some small peaks are observed in the morning, at noon and in the late evening (Fig. 3). The average relative contribution of this factor is $10 \%$ in winter.

\subsubsection{Summer PMF profile identification and contribution}

One of the limitations of PMF application for summer data could be the effect of the photochemistry (Yuan et al., 2012). The effect of photochemistry has been assessed in Salameh et al. (2015), and the results showed a limited influence of the photochemistry in summer.

The five sources identified by the PMF analysis in summer correspond to combustion related (so-called nocturnal and diurnal) to traffic, gasoline evaporation related to traffic, gasoline evaporation as an episodic point source and a source characterizing the local background. The composition of the source profiles and the diurnal variation of the source contribution are reported respectively in Figs. 7 and 8.

\section{Local background}

$64 \%$ of the variability of isoprene, commonly used as the tracer of biogenic emissions, is explained by the factor 1 . The profile of this factor consists largely of toluene, ethane, isopentane, m,p-xylenes, acetylene, butane and propene which are related to combustion. Therefore, "local background" is attributed to this factor including the regional background, the combustion from the surrounding sources, as well as the biogenic emissions from the forest nearby the measurement site. It is not possible to separate this type of

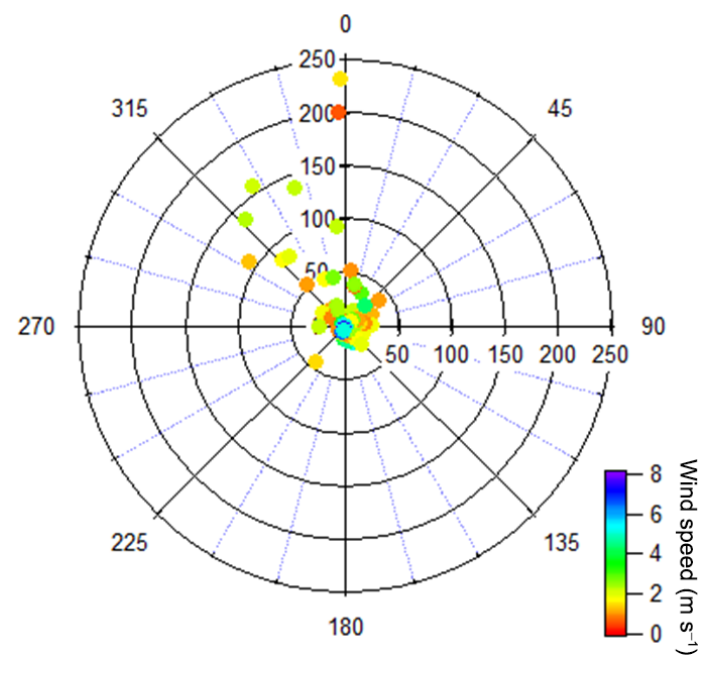

Figure 6. Pollution rose by a factor of 5 contribution $\left(\mu \mathrm{g} \mathrm{m}^{-3}\right)$ in winter.

source even by increasing the number of PMF factors. The diurnal profile shows higher contributions during the day starting 07:00-08:00 LT and lower contributions during the night. The average relative contribution of this factor is $10 \%$ in summer.

\section{Traffic-related sources}

Two profiles (factor 2 and factor 3 ) related to traffic have been extracted with different contributions between day and night.

The profile of factor 2 is essentially composed of aromatic compounds toluene, $\mathrm{m}, \mathrm{p}$-xylenes, $\mathrm{o}$-xylene, ethylbenzene, 1,2,4-trimethylbenzene and decane (co-eluted), ethylene, acetylene and isopentane which are included in the traffic related sources (gasoline evaporation and combustion, Fig. 9) and are present in the composition of factor F2 in winter (especially the aromatics). The diurnal variation shows high loadings during the day (Fig. 8). A significant first increase is observed at 07:00-08:00 LT (UTC/GMT+3 h), two other small peaks are observed during the afternoon (14:00 15:00 LT) and in evening (20:00-21:00 LT) comparable to the peaks observed in the combustion related to traffic during winter (winter F2). This factor is linked to traffic emissions occurring during the day and coming mainly from the southwest sector. The average relative contribution of this factor, combustion related to diurnal traffic, is $17 \%$ in summer.

Typical combustion tracers are the major contributors to the profile of the factor 3 . The variability of acetylene $(34 \%)$, ethylene ( $43 \%)$, propene $(45 \%)$ and benzene $(30 \%)$ is mostly explained by this factor. The daily variability of this factor displays high contributions during nighttime characterizing the combustion related mainly to nocturnal traffic. At night, the wind direction is mostly from the northeast, the south, and southwest where the highway network is densely 

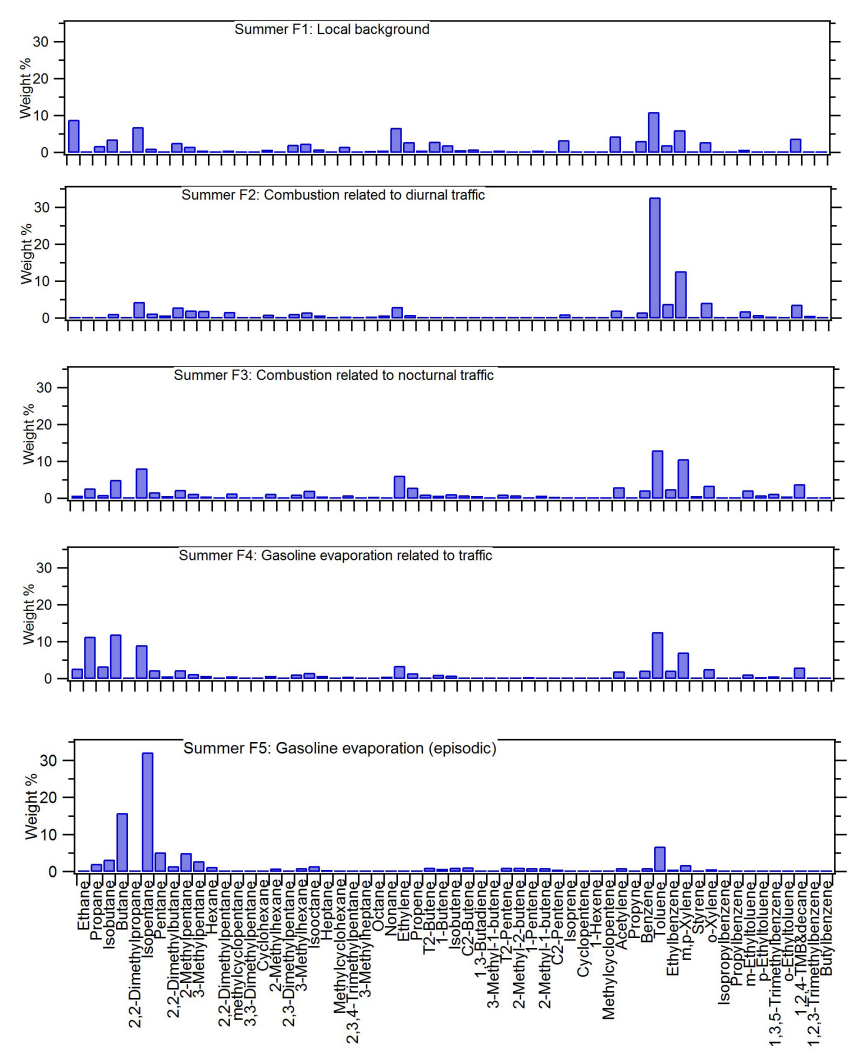

Figure 7. Source composition profiles (relative abundance of specific compounds within each factor in wt \%) in summer 2011.

occupied at night in summer and the vehicles run slowly. When the vehicles speed is low, especially in the case of vehicles running on gasoline without a functioning catalytic converter (Waked and Afif, 2012), the NMVOC emissions increase (Fontaine, 2000). The average relative contribution of this factor is $27 \%$ in summer.

\section{Gasoline evaporation related to traffic}

Factor 4 encloses a high percentage of butane, toluene, propane, m,p-xylenes and isopentane which strongly suggests that this factor is related to the gasoline evaporation. This factor exhibits also high loadings during nighttime alike the combustion related to nocturnal traffic factor 3 confirming the traffic as the origin of these two factors (F3 and F4).

By comparing both combustion (F2 and F3) and gasoline evaporation (F4) factors related to traffic profiles with the road transport profile established in near-field measurements (Salameh et al., 2014), which consists of exhaust and evaporative running losses from vehicles (Fig. 9), we notice the same overall fingerprint for the majority of the species, nevertheless, propane exhibits a high percentage in the gasoline evaporation profile and $75 \%$ of its variability is explained by this factor (F4), suggesting the liquefied petroleum gas leak-

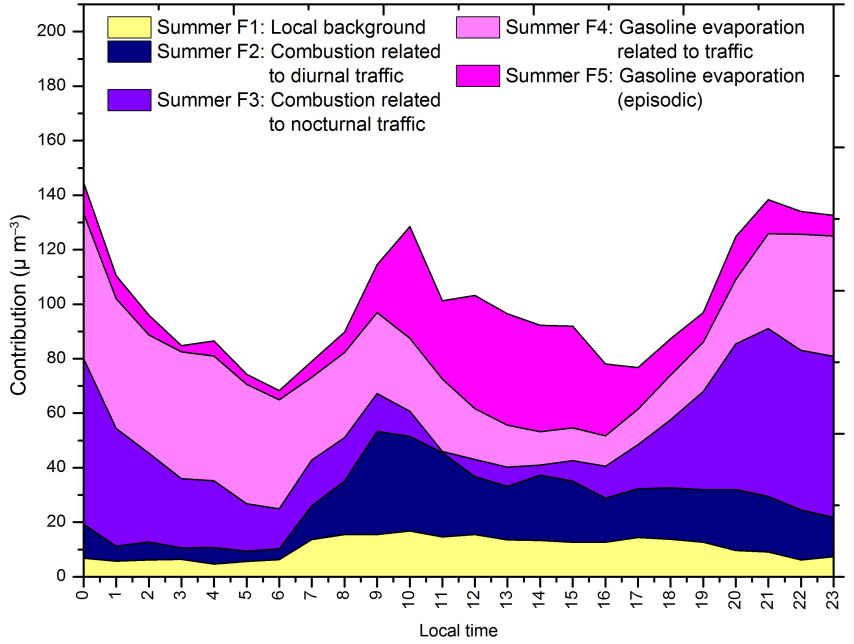

Figure 8. Diurnal variation of sources contribution $\left(\mu \mathrm{g} \mathrm{m}^{-3}\right)$ in summer 2011 (local time).

age as an additional source to the gasoline evaporation. The average relative contribution of this factor is $30 \%$ in summer.

\section{Gasoline evaporation (episodic point source)}

Factor 5 is characterized by C4-C5 alkanes, toluene and 2methylpentane similar to the factor 5 composition in winter. This factor is gasoline evaporation showing a high contribution in the middle of the day. The pollution rose, as in winter, shows high contributions coming from the north sector, where the fuel storage facilities are located, as shown in Fig. 10 which corresponds to episodic events having occurred on 7,8 and 9 July. The average relative contribution of this factor is $16 \%$ in summer.

\section{Similarities and differences between summer and winter results}

Figure 11 summarizes the average relative contribution in weight $\%$ of each factor in winter and in summer. We found several common factors in winter and summer but their relative contribution was slightly different. For instance, the contribution of traffic-related sources including the combustion and the gasoline evaporation from traffic accounted for $51 \%$ in winter and $74 \%$ in summer. Nevertheless, the episodic gasoline evaporation source contributed to $21 \%$ in winter and $16 \%$ in summer. This source was a major contributor to winter's NMHC concentrations reflecting the importance of gasoline evaporation in winter. If we consider the gasoline evaporation sources (episodic and related to traffic), we obtain a significant contribution of $43 \%$ in winter and $46 \%$ in summer.

Additional factors were found in winter but absent in summer: for instance, gas leakage due to the use of LPG in res- 


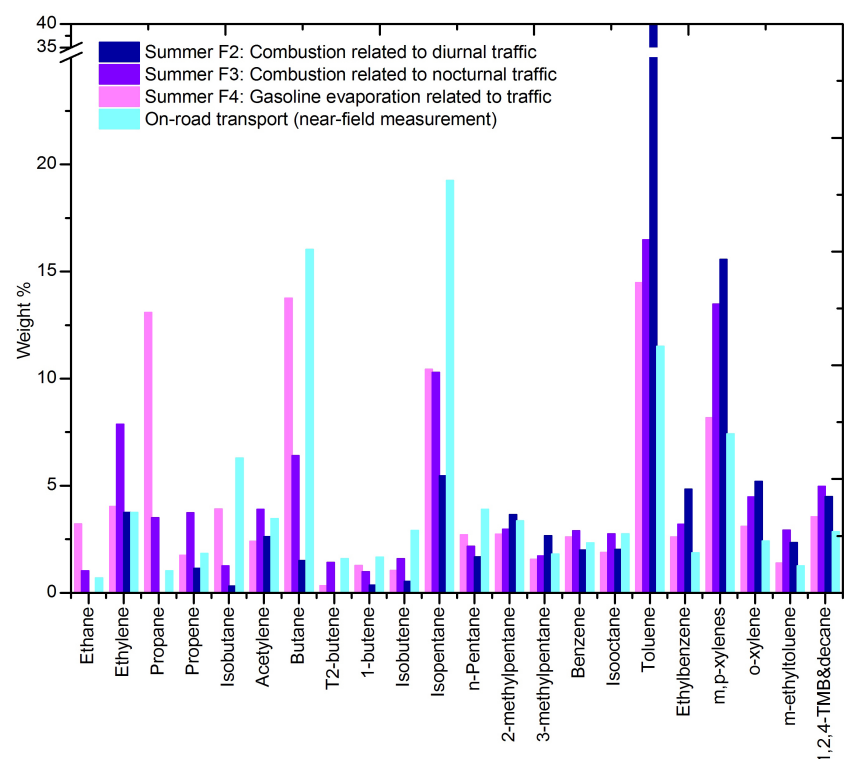

Figure 9. Source composition profiles (wt \%) of combustion related to diurnal and nocturnal traffic (F2 and F3) and gasoline evaporation (F4) in summer compared to the on-road transport profile established by near-field measurements (Salameh et al., 2014).

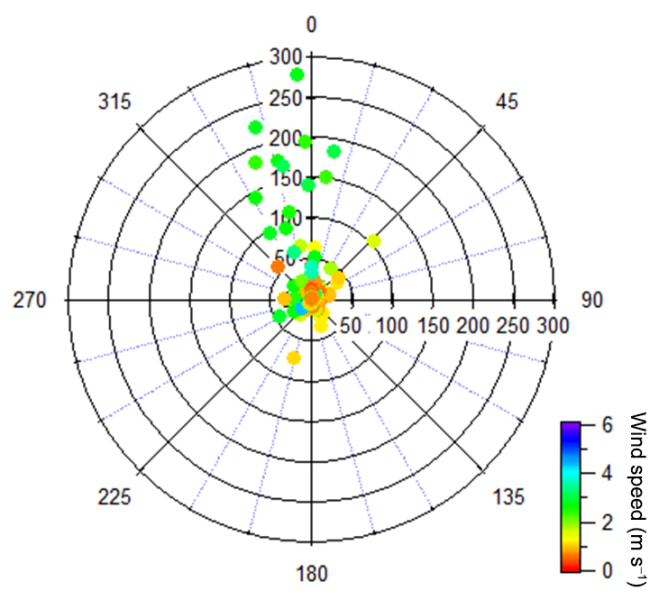

Figure 10. Pollution rose of factor 5 contribution $\left(\mu \mathrm{g} \mathrm{m}^{-3}\right)$ in summer.

idential heating. Another factor is characterizing the urban background highly contributed to winter's NMHC concentrations (18\%) mainly because of the meteorological conditions and the absence of photochemistry in winter (Salameh et al., 2015). A source characterizing the "local background" including the biogenic emissions was exclusively found in summer since the meteorological conditions are favorable. Nevertheless, this "local background" also includes regional background and combustion emissions.

Based on the PMF analysis, we conclude that the main contributors to the NMHCs are the combustion and gasoline evaporation sources in summer as well as in winter. These

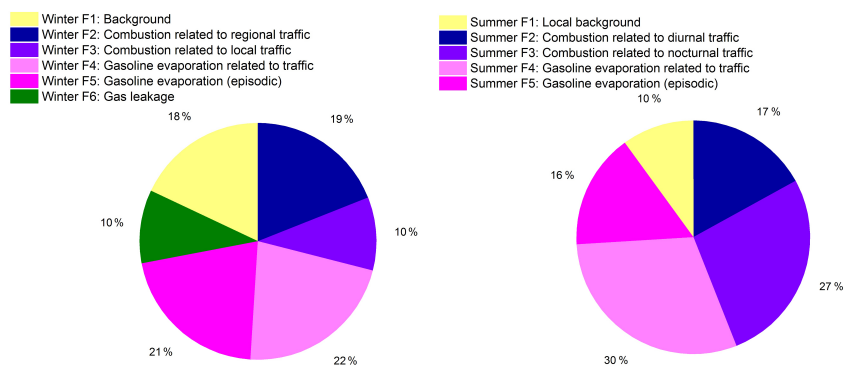

Figure 11. Sources contribution (wt \%) in winter and in summer.

sources are of local origin confirming what has been demonstrated previously (Salameh et al., 2015) that there is no significant influence of long-range transport of air masses on the NMHC concentrations.

\section{Comparison of PMF results to emission inventories}

Our study provides the first comprehensive observational constraints for a quantitative evaluation of anthropogenic emission inventories at local, national (Waked et al., 2012) and global levels for a Middle Eastern area. While such a comparison is somewhat limited as the basis for comparison is different (NMHC speciation, number of NMHCs, temporal and spatial resolution), it still provides relevant insights on uncertainties and perspectives of improvement.

\subsection{The annual national emission inventory (NEI) for Lebanon}

The contribution of the factors discussed above is dependent on the seasons and associated meteorological conditions, therefore, care must be taken when comparing these results to the annual national emission inventory (NEI) for Lebanon.

The NEI is not speciated, and was established for a base year of 2010 within the EEA/EMEP guidelines, by Waked et al. (2012), covering major anthropogenic and biogenic sources in the region with $5 \mathrm{~km}$ spatial resolution for Lebanon and $1 \mathrm{~km}$ spatial resolution for its capital city Beirut and its suburbs. The total VOC emissions in Lebanon were estimated to be $115 \mathrm{Gg}$ for the year 2010. According to this inventory, transport is the main source of NMVOCs with a relative contribution of $67 \%$ of total emissions of VOCs in Beirut and its suburbs as well as all over Lebanon. PMF results give nearly the same contribution of this sector in winter 51 and $74 \%$ in summer. According to Waked and Afif (2012), the gasoline evaporation contribution was evaluated to be responsible for $8 \%$ of total NMVOC emissions in Beirut and its suburbs and $17 \%$ of total NMVOC emissions at the national level based on gasoline consumption whereas the PMF gasoline evaporation (related to traffic) sources contributed to $22 \%$ in winter and $30 \%$ in summer. 
The comparison held here is subject to several limitations. On one hand, the national emission inventory is not speciated, and it needs further improvements regarding the input data and the Lebanon-specific emission factors need to be established (Waked et al., 2012). On the other hand, the measurement site is qualified as suburban and is located far from some sources identified in the inventory, like for instance large forests representing biogenic sources, and industrial plants. These sources have not been identified in the PMFresolved profiles since they were not major sources during this study and some of them are located in the north and south of Lebanon far away from the measurement site. Additionally, it was hard to discern the biogenic source since the key tracers of this source such as terpenes and oxygenated volatile organic compounds (methanol, acetone...) were not included in the PMF analysis. Furthermore, the emission inventory data used for comparison are provided on annual statistical data, on a national scale whereas the data here are obtained from a single measurement site during a shorter time regarding a non-exhaustive list of species. Therefore, longterm and continuous studies integrating more than one measuring site and more specific tracers are of great interest in order to provide more reliable information.

\subsection{Emission inventories for road transport}

The objective of this last section is to estimate NMHC emissions from the road transport sector from PMF results and carbon monoxide observations and to compare these values to the ones derived from various emission inventories.

\subsubsection{National emission inventory for Lebanon -NEI-}

The annual emissions of air pollutants originating from onroad mobile sources in 2010 in Beirut specifically and in Lebanon were investigated by Waked and Afif (2012). At a national level, the estimated annual emissions for $\mathrm{CO}$ were 522 and $48 \mathrm{Gg}$ for NMVOCs by using the EMEP methodology (Waked and Afif, 2012). In parallel, we calculated separately, for each season, the ratio of the sum of the $59 \mathrm{NMHC}$ contributions (in $\mu \mathrm{g} \mathrm{m}^{-3}$ ) coming from the PMF factors related to road transport (combustion and gasoline evaporation) and of the mean of the $\mathrm{CO}$ measured (in $\mu \mathrm{g} \mathrm{m}^{-3}$ ) during each measurement campaign according to Eq. (6). Then, we used the estimated annual emissions for $\mathrm{CO}(Q)$ in $\mathrm{Gg}$ to generate the emissions of the 59 NMHCs based on the winter ratio on one hand, and on the summer ratio on the other hand, in order to give a range of annual emissions levels.

$\mathrm{NMHC}=\operatorname{ratio}(\mathrm{NMHC} / \mathrm{CO})_{\mathrm{ECOCEM}} \times Q_{\mathrm{CO}}$ inventory

With NMHC $=$ Sum of 59 measured species during ECOCEM (in Gg).

The mean concentration of $\mathrm{CO}$ was equal to $470 \pm 195 \mu \mathrm{g} \mathrm{m}^{-3}$ during the summer campaign, while it was equal to $388 \pm 228 \mu \mathrm{g} \mathrm{m}^{-3}$ during the winter cam- paign. The measured NMHC to CO ratio was estimated to be 0.15 in summer and 0.12 in winter.

By this method, the annual emissions for Lebanon are estimated to be $78 \mathrm{Gg}$ from the summer ratio and $62 \mathrm{Gg}$ by the winter ratio, which are higher than the annual emissions of $48 \mathrm{Gg}$. In both cases, the emissions from the national road transport inventory are lower with a reasonable difference ranging from $22 \%$ for winter-based emissions to $39 \%$ for summer-based emissions (Fig. 12). By applying the same calculation method for Beirut and its suburbs, the annual emissions obtained using the summer ratio are estimated to be $29 \mathrm{Gg}$ higher than the annual emissions calculated based on winter ratio ( $23 \mathrm{Gg}$ ) (Fig. 12).

The measurements we conducted are more representative of Beirut and its suburbs (Greater Beirut Area). The emissions from the inventory regarding the road transport for Greater Beirut Area are also lower with a difference ranging from $20 \%$ for winter-based emissions to $37 \%$ for summerbased emissions.

The discrepancies for Lebanon as well as for Beirut and its suburbs using winter and summer ratios are comparable since the road transport is the dominating sector in the whole country and especially in the capital.

\subsubsection{Global emission inventories}

The objective here is to assess the PMF estimated emissions to the global emission inventories for the road transport sector for 59 NMHCs and, where possible, for a common combustion tracer "ethylene" which is also an ozone precursor due to its reactivity towards the $\mathrm{OH}$ radical (Atkinson and Arey, 2003).

We estimated the annual total NMVOCs emissions for Lebanon by using a mean flux of total NMVOCs of eight grids covering Lebanon surface area (ECCAD database) from the transportation sector from the global historical emission inventory ACCMIP (Atmospheric Chemistry and Climate Model Intercomparison Project) (Lamarque et al., 2010) for 2000 at a spatial resolution of $0.5^{\circ}$. The total annual NMVOCs transportation emissions from the ACCMIP are estimated to be $8 \mathrm{Gg}$, which is a factor of 6 to 10 lower than the annual emissions obtained via the PMF results (62 to $78 \mathrm{Gg}$ ) and the road transport national inventory emissions $(48 \mathrm{Gg})$. This gap is expected to be a lower limit regarding the fact that PMF only considers 59 NMHCs. Nevertheless, when we apply the same method to another global inventory EDGARv4.2 (Emissions Database for Global Atmospheric Research) at a spatial resolution of $0.5^{\circ}$, the annual transportation emissions are estimated to be $23 \mathrm{Gg}$, which is a factor of 2 to 3 lower than the road transport national inventory emissions and the annual emissions obtained via the PMF results. This comparison also reveals that global inventories are not consistent between each other. Additionally, the global inventories do not describe the methodologies applied 

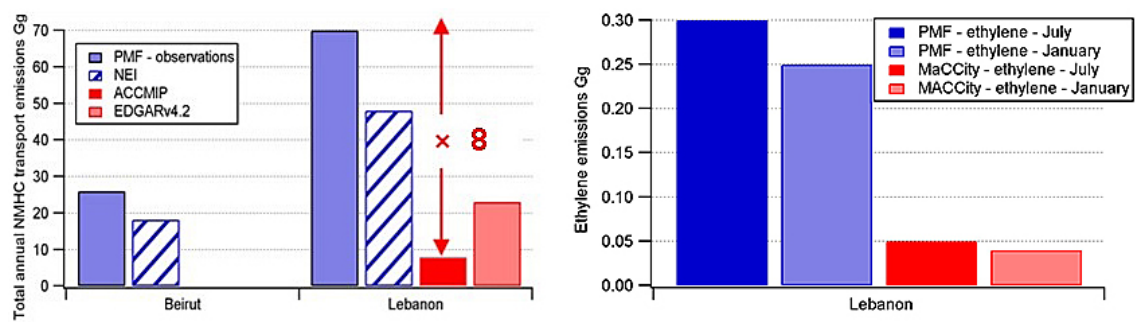

Figure 12. Comparison of the PMF results and emission inventories (national and global) for the transport sector emissions.

nor the data used (emission factors, NMVOC species considered...).

For a more detailed evaluation of speciation accuracy, we compared the emissions of an individual NMHC, ethylene, obtained by the PMF results according to Eq. (6), where NMHC represents ethylene, to the emissions from a speciated inventory having a monthly temporal resolution, over the same period, called MACCity. The MACCity global emission inventory has been developed within two European Commission funded projects (MACC and CityZen) as an extension of the ACCMIP and RCP8.5 (Representative Concentrations Pathways) emission inventories (Granier et al., 2011) at a spatial resolution of $0.5^{\circ}$. Based on the PMF results, the emissions of ethylene during July 2011 are estimated to 0.30 and $0.25 \mathrm{Gg}$ during January 2012 for Lebanon. The MACCity global emission inventory displays very low ethylene emissions from the transportation sector (ECCAD database) during July $2011(0.05 \mathrm{Gg})$ and during January $2012(0.04 \mathrm{Gg})$ for Lebanon (Fig. 12). The difference with the PMF results is by a factor of 6 .

\subsubsection{Comparison of the PMF results with the NEI and the global emission inventories}

The comparison of the PMF results to the NEI for Lebanon as well as for Beirut and its suburbs suggests that the inventory underestimates the road transport emissions in a reasonable way (20 to $39 \%)$. Whereas the comparison of the PMF results to the global emission inventories shows significant differences reaching a factor of 10 .

Taking into account uncertainties, when comparing PMF results to emission inventory, is not easily achievable due to the multiple sources of uncertainties. First, the uncertainty of the global emission inventory itself and, in particular, of the estimated annual emissions of $\mathrm{CO}(Q)$ (Eq. 6), is unknown. To get a sense of uncertainties one can compare emission amounts provided by different emission inventories which cannot be applied here. Second, the confidence intervals of the PMF results were not assessed. However, when comparing PMF to emission inventory, one could consider the standard deviation and the coefficient of variation (CV) of each PMF factor contribution in order to get an idea of the variability of the PMF factors contributions in each season.
Our calculation shows a high variability of the PMF factors contributions in both seasons including the transport-related factors (coefficients of variation around $100 \%$ ). We can rely on this variability to test whether differences between PMF and emission inventory are significant or not. On the one hand, for the Lebanese NEI, the differences are not significant (lower than $100 \%$ ). For the global emission inventory, differences are higher by a factor of 6 to 10 which is significant and higher than $100 \%$.

\section{Conclusions}

Measurements of 67 gaseous organic carbon have been performed at a suburban site in Beirut during two intensive field campaigns in summer 2011 and in winter 2012 within the framework of the ECOCEM project, resulting in a large and unique database, in order to improve our understanding of their major emission sources in the area.

The USEPA PMF v3.0 was applied to the winter and summer data sets in order to identify and quantify the source contribution. Six factors were then extracted in winter and five factors in summer. Source profiles established close to the main potential emitters by near-field measurements (Salameh et al., 2014) were used to identify the PMF factors.

In winter, the six NMHC emission factors consist of traffic-related sources including combustion mainly related to regional traffic, combustion related to local traffic and gasoline evaporation from vehicles accounting for $51 \%$. In summer, the combustion and gasoline evaporation related to regional traffic contributed to $74 \%$ of which $57 \%$ are nocturnal. Additionally, an episodic gasoline evaporation source originating principally from the fuel storage facilities was identified in winter and in summer contributing to 21 and $16 \%$ respectively. The gas leakage, mainly LPG, contributes to $10 \%$ and the urban background to $18 \%$ of the ambient NMHC levels during winter. A factor characterizing local background was identified in summer contributing to $10 \%$. Having similar species composition profiles, we found a difficulty in discerning the combustion related to power generators, running on diesel oil, within the combustion sources, hence, additional species (e.g., $\mathrm{PM}_{2.5}$ species measured with high temporal resolution) may have helped to extract this source. 
Overall, the gasoline evaporation contribution (related to traffic and the episodic point source) was found to be a large contributor to the NMHC ambient concentrations: $43 \%$ in winter and $46 \%$ in summer.

Control measures should be developed to mitigate the NMHC emissions resulting from traffic-related sources (combustion and gasoline evaporation).

Verification of the reported emission inventory for Lebanon and Greater Beirut Area can assist in the evaluation of future control strategy effectiveness. The comparison of the modeled results to the emission inventory shows an agreement regarding the load of the on-road mobile source, by considering the vehicle exhaust and gasoline evaporation linked to traffic, in both seasons. Nevertheless, the gasoline evaporation related to traffic is lower in the inventory $(17 \%)$ by considering PMF summer results (30\%) suggesting a slight underestimation of the inventory. We assessed also the accuracy of several global inventories for the transportation sector and high discrepancies up to a factor of 10 still remain between the emission inventories.

To maximize current resources, continuous measurement of NMHC species and the implementation of ground-based monitoring networks for ambient air quality monitoring and assessment are essential in order to conduct source apportionment which would be of less uncertainty and of greater help in establishing effective NMHC, ozone and PM abatement strategies in Lebanon.

Acknowledgements. Funding for this study was obtained from Mines Douai Institution, the Lebanese National Council for Scientific Research, Saint Joseph University (Faculty of Sciences and the Research Council), CEDRE (Coopération pour l'Évaluation et le Développement de la Recherche) and PICS no. 5630 (Programme Interorganismes de Coopération Scientifique du CNRS). This work is also part of the ChArMEx programme. ChArMEx is the atmospheric component of the French multidisciplinary program MISTRALS (Mediterranean Integrated Studies aT Regional And Local Scales). ChArMEx-France was principally funded by INSU, ADEME, ANR, CNES, CTC (Corsica region), EU/FEDER, Météo-France and CEA.

Edited by: N. Mihalopoulos

\section{References}

Afif, C., Dutot, A., Jambert, C., Abboud, M., Adjizian-Gérard, J., Farah, W., Perros, P., and Rizk, T.: Statistical approach for the characterization of $\mathrm{NO}_{2}$ concentrations in Beirut, Air Quality, Atmosphere and Health, 2, 57-67, doi:10.1007/s11869-0090034-2, 2009.

Atkinson, R. and Arey, J.: Atmospheric degradation of volatile organic compounds, Chem. Rev., 103, 4605, doi:10.1021/CR0206420, 2003.

Badol, C., Locoge, N., and Galloo, J. C.: Using a source-receptor approach to characterise VOC behaviour in a French urban area influenced by industrial emissions: Part II: source contribution assessment using the Chemical Mass Balance (CMB) model, Sci. Total Environ., 389, 29-440, 2008.

Blake, D. R. and Rowland, F. S.: Urban leakage of liquefied petroleum gas and its impact on Mexico City air quality, Science, 269, 953-956, 1995.

Borbon, A., Gilman, J. B., Kuster, W. C., Grand, N., Chevaillier, S., Colomb, A., Dolgorouky, C., Gros, V., Lopez, M., SardaEsteve, R., Holloway, J., Stutz, J., Perrussel, O., Petetin, H., McKeen, S., Beekmann, M., Warneke, C., Parrish D. D., and de Gouw, J. A.: Emission ratios of anthropogenic VOC in northern mid-latitude megacities: observations vs. emission inventories in Los Angeles and Paris, J. Geophys. Res., 118, 2041-2057, doi:10.1002/jgrd.50059, 2013.

Carter, W. P. L.: Development of Ozone Reactivity Scales for Volatile Organic Compounds, J. Air Waste Manage., 44, 881899, 1994.

Derwent, R. G, Jenkin, M. E., Utembe, S. R., Shallcross, D. E., Murrells, T. P., and Passant, N. R.: Secondary organic aerosol formation from a large number of reactive man-made organic compounds, Sci. Total Environ., 408, 3374-3381, 2010.

ECCAD database: available at: http://eccad.sedoo.fr/eccad_extract_ interface/JSF/page_products_em.jsf, last access: July 2015.

EMEP/EEA: Air pollutant emission inventory guidebook, available at: http://www.eea.europa.eu (last access: July 2015), 2009.

Fontaine, H.: Les Composés Organiques Volatils dans les gaz d'échappement des automobiles: Etablissement de profils d'émission représentatifs de différentes conditions de conduite, Thesis, Department of Chemistry and Environment, Ecole des Mines de Douai, Douai, France, April 2000.

Friedrich, R. and Obermeier, A.: Anthropogenic emissions of VOCs, in: Reactive Hydrocarbons in the Atmosphere, edited by: Hewitt, C. N., Academic Press, San Diego, CA, USA, 1-39, 1999.

Gaimoz, C., Sauvage, S., Gros, V., Herrmann, F., Williams, J., Locoge, N., Perrussel, O., Bonsang, B., d'Argouges, O., SardaEsteve, R., and Sciare, J.: Volatile organic compounds sources in Paris in spring 2007, Part II: source apportionment using positive matrix factorization, Environ. Chem., 8, 91-103, 2011.

Granier, C., Bessagnet, B., Bond, T., D’Angiola, A., van der Gon, H. D., Frost, G. J., Heil, A., Kaiser, J. W., Kinne, S., Klimont, Z., Kloster, S., Lamarque, J.-F., Liousse, C., Masui, T., Meleux, F., Mieville, A., Ohara, T., Raut, J.-C., Riahi, K., Schultz, M. G., Smith, S. J., Thompson, A., van Aardenne, J., van der Werf, G. R., and van Vuuren, D. P.: Evolution of anthropogenic and biomass burning emissions of air pollutants at global and regional scales during the 1980-2010 period, Climatic Change, 109, 163-190, doi:10.1007/s10584-011-0154-1, 2011.

Guo, H., So, K. L., Simpson, I. J., Barletta, B., Meinardi, S., and Blake, D. R.: C1-C8 volatile organic compounds in the atmosphere of Hong Kong: Overview of atmospheric processing and source apportionment, Atmos. Environ., 41, 1456-1472, 2007.

Hoerger, C. C., Claude, A., Plass-Duelmer, C., Reimann, S., Eckart, E., Steinbrecher, R., Aalto, J., Arduini, J., Bonnaire, N., Cape, J. N., Colomb, A., Connolly, R., Diskova, J., Dumitrean, P., Ehlers, C., Gros, V., Hakola, H., Hill, M., Hopkins, J. R., Jäger, J., Junek, R., Kajos, M. K., Klemp, D., Leuchner, M., Lewis, A. C., Locoge, N., Maione, M., Martin, D., Michl, K., Nemitz, E., O’Doherty, S., Pérez Ballesta, P., Ruuskanen, T. M., Sauvage, S., 
Schmidbauer, N., Spain, T. G., Straube, E., Vana, M., Vollmer, M. K., Wegener, R., and Wenger, A.: ACTRIS non-methane hydrocarbon intercomparison experiment in Europe to support WMO GAW and EMEP observation networks, Atmos. Meas. Tech., 8, 2715-2736, doi:10.5194/amt-8-2715-2015, 2015.

Lamarque, J.-F., Bond, T. C., Eyring, V., Granier, C., Heil, A., Klimont, Z., Lee, D., Liousse, C., Mieville, A., Owen, B., Schultz, M. G., Shindell, D., Smith, S. J., Stehfest, E., Van Aardenne, J., Cooper, O. R., Kainuma, M., Mahowald, N., McConnell, J. R., Naik, V., Riahi, K., and van Vuuren, D. P.: Historical (1850-2000) gridded anthropogenic and biomass burning emissions of reactive gases and aerosols: methodology and application, Atmos. Chem. Phys., 10, 7017-7039, doi:10.5194/acp10-7017-2010, 2010.

Lanz, V. A., Hueglin, C., Buchmann, B., Hill, M., Locher, R., Staehelin, J., and Reimann, S.: Receptor modeling of C2-C7 hydrocarbon sources at an urban background site in Zurich, Switzerland: changes between 1993-1994 and 2005-2006, Atmos. Chem. Phys., 8, 2313-2332, doi:10.5194/acp-8-2313-2008, 2008.

Lee, E., Chan, C. K., and Paatero, P.: Application of positive matrix factorization in source apportionment of particulate pollutants in Hong Kong, Atmos. Environ., 33, 3201-3212, 1999.

Leuchner, M. and Rappenglück, B.: VOC source-receptor relationships in Houston during TexAQS-II, Atmos. Environ., 44, 40564067, 2010.

Massoud, R., Shihadeh, A., Roumié, M., Youness, M., Gerard, J., Saliba, N., Zaarour, R., Abboud, M., Farah,W., and Saliba, N. A.: Intraurban variability of $\mathrm{PM}_{10}$ and $\mathrm{PM}_{2.5}$ in an Eastern Mediterranean city, Atmos. Res., 101, 893-901, 2011.

Miller, S. L., Anderson, M. J., Daly, E. P., and Milford, J. B.: Source apportionment of exposures to volatile organic compounds. I. Evaluation of receptor models using simulated exposure data, Atmos. Environ., 36, 3629-3641, 2002.

Niedojadlo, A., Becker, K. H., Kurtenbach, R., and Wiesen, P.: The contribution of traffic and solvent use to the total NMVOC emission in a German city derived from measurements and CMB modeling, Atmos. Environ., 41, 7108-7126, 2007.

Paatero, P.: A weighted non-negative least squares algorithm for three-way "PARAFAC" factor analysis, Chemometr. Intell. Lab., 38, 223-242, 1997.

Paatero, P. and Hopke, P. K.: Discarding or downweighting highnoise variables in factor analytic models, Anal. Chim. Acta, 490, 277-289, 2003

Paatero, P. and Tapper, U.: Positive MAtrix Factorization: a nonnegative factor model with optimal utilization of error estimates of data values, Environmetrics, 5, 111-126, 1994.

Salameh, T., Afif, C., Sauvage, S., Borbon, A., and Locoge, N.: Speciation of Non-Methane Hydrocarbons (NMHC) from anthropogenic sources in Beirut, Lebanon, Environ. Sci. Pollut. Res., 21, 10867-10877, doi:10.1007/s11356-014-2978-5, 2014.
Salameh, T., Sauvage, S., Afif, C., Borbon, A., Leonardis, T., Brioude, J., Waked, A., and Locoge, N.: Exploring the seasonal NMHC distribution in an urban area of the Middle East during ECOCEM campaigns: very high loadings dominated by local emissions and dynamics, Environ. Chem., 12, 316-328, doi:10.1071/EN14154, 2015.

Sarraf, M., Larsen, B., and Owaygen, M.: Cost of Environmental Degradation - The Case of Lebanon and Tunisia, The World Bank Environment Department, Washington, D.C., 2004.

Sauvage, S., Plaisance, H., Locoge, N., Wroblewski, A., Coddeville, P., and Galloo, J. C.: Long term measurement and source apportionment of non-methane hydrocarbons in three French rural areas, Atmos. Environ., 43, 2430-2441, 2009.

Seinfeld, J. H. and Pandis, S. N.: Atmospheric chemistry and physics, from air pollution to climate change, John Wiley \& Sons, inc., Hoboken, NJ, USA, 2006.

UNEP - United Nations Environment Programme and Regional Office for West Asia: Air Quality and Atmospheric Pollution In the Arab Region, edited by: El-Raey, M., ESCWA/League of Arab States/UNEP, Regional Office for West Asia Report, available at: http://www.un.org/esa/sustdev/csd/csd14/escwaRIM_bp1.pdf (last access: July 2015), 2006.

Waked, A. and Afif, C.: Emissions of air pollutants from road transport in Lebanon and other countries in the Middle East region, Atmos. Environ., 61, 446-452, 2012.

Waked, A., Afif, C., and Seigneur, C.: An atmospheric emission inventory of anthropogenic and biogenic sources for Lebanon, Atmos. Environ., 50, 88-96, 2012.

Waked, A., Seigneur, C., Couvidat, F., Kim, Y., Sartelet, K., Afif, C., Borbon, A., Formenti, P., and Sauvage, S.: Modeling air pollution in Lebanon: evaluation at a suburban site in Beirut during summer, Atmos. Chem. Phys., 13, 5873-5886, doi:10.5194/acp13-5873-2013, 2013.

WHO - World Health Organisation: Air Quality Guidelines for Europe, 2nd Edn., WHO Regional Publications, No. 91, European Series, Copenhagen, 2000.

WHO: Air quality guidelines for particulate matter, ozone, nitrogen dioxide and sulfur dioxide, Global update, Bonn, Germany, 2005.

Yuan, B., Shao, M., de Gouw, J., Parrish, D. D., Lu, S., Wang, M., Zeng, L., Zhang, Q., Song, Y., Zhang, J., and Hu, M.: Volatile organic compounds (VOCs) in urban air: How chemistry affects the interpretation of positive matrix factorization (PMF) analysis, J. Geophys. Res.-Atmos., 117, D24302, doi:10.1029/2012JD018236, 2012.

Yuan, Z., Zhong, L., Lau, A. K. H., Yu, J. Z., and Louie, P. K. K.: Volatile organic compounds in the Pearl River Delta: Identification of source regions and recommendations for emissionoriented monitoring strategies, Atmos. Environ., 76, 162-172, 2013. 